Cite: Arulraj, A., \& Rena, R. (2021). Mediating Effects on Poverty Reduction in India Through Mahatma Gandhi National Rural Employment Guarantee Programme. Demohrafiia ta sotsialna ekonomika Demography and Social Economy, 3 (45), 100-119. https://doi.org/10.15407/dse2021.03.100

https://doi.org/10.15407/dse2021.03.100

УДК $311,331.5,364.22$

JEL CLASSIFICATION: C12, H11, I32

A. ARULRAJ, Dr., Assistant Professor, P.G. \& Research Department of Economics
Rajah Serfoji Government College
Thanjavur-613 005, Tamilnadu, India
Email: arulraj.antony@gmail.com
ORCID: 0000-0002-0767-8231

R. RENA, Prof., Dr. Professor of Economics,

NWU Business School, North-West University - Mahikeng Campus

Private Bag: X 2046, Mmbatho, 2745, South Africa,

Email: ravinder.rena@gmail.com

ORCID: 0000-0002-4156-8693

Scopus ID: 56441653000

\title{
MEDIATING EFFECTS ON POVERTY REDUCTION IN INDIA THROUGH MAHATMA GANDHI NATIONAL RURAL EMPLOYMENT GUARANTEE PROGRAMME
}

The employment opportunities in rural areas have significantly decreased for the last few decades in India. Therefore, Government of India introduced Mahatma Gandhi National Rural Employment Guarantee Programme (MGNREGP) to create employment opportunities for rural people. The Programme is considered as a "silver bullet" for eradicating rural poverty and unemployment in India. The purpose of this empirical research study is to develop a new model for poverty reduction in rural India through this Programme. The novelty of this article is an attempt to develop an empirical research model that assists the Mahatma Gandhi National Rural Employment Guarantee Programme when mapping the level of economics service quality and thereby enhance the same. This Programme provides an alternative source of livelihood, which will have an impact on reducing migration, restricting child labor, alleviating poverty, and making villages self-sustaining through productive assets creation such as road construction, cleaning up of water tanks, soil and water conservation work, etc. for which it has been considered as the largest anti-poverty programme in the world. The paper critically examines the implementation process of this Programme and its impact on tribal livelihoods. The following research methodology is used in the article: the data were collected using a structured questionnaire. The sampling procedure used for this study is stratified random sampling. The stratification is done based on the Taluks are Kumbakonam (Thanjavur District), Keeranur (Pudukottai District) 
and Nagappatinam (Nagappatinam District) of Tamilnadu state of South-India for the nature of region South, East, Centre, West and North while selecting the MGNREGP Employees from each category, non-probabilistic convenience and judgmental sampling technique is used. The findings and conclusions of the study reveal that millions of rural poor with the inclusion of new works under this Programme could able to get some employment which supports their livelihoods. Efforts are exerted to improve more transparency and accountability in implementing this programme to ensure that the benefits reach out to the poor and the needy villagers. The regression analysis revealed that the Poverty Eradication on the various dimensions of Economic Development, influenced Economic Development followed by Social Development. The visual representation of results suggest that the relationships between the dimensions of Economic Development, Social development resulted in a significant impact on the mediated factor 'Poverty Eradication'. The paper suggests the policy framework for the stakeholders in effective implementation of the Programme.

Keywords: modelling, mediating effects, poverty reduction, Mahatma Gandhi National Rural Employment Guarantee Programme, economics service quality, India and service quality assurance.

Introduction. Rural poverty and unemployment in India have grown in an unprecedented manner during the last few decades. There is a growing incidence of illiteracy, blind faith, hungry people, malnourished children, anaemic pregnant women, farmer suicides, starvation deaths, migration resulting from inadequate employment, poverty, and the failure of subsistence production during droughts. To make the solution to these problems and to provide livelihood security to the rural unemployed, the Government of India (GOI) enacted the National Rural Employment Guarantee Act (NREGA) in September 2005.

Relevance of research. The GOI introduced one of the largest development programmes in human history, the National Rural Employment Guarantee Scheme (NREGS). The NREGS came into effect, on a pilot basis, on February 2, 2006 in 200 economically disadvantaged districts of the country. In the second phase of implementation, it was extended to 130 additional districts, and the remaining districts were covered in the third phase on April 1, 2008 (Ambasta, et all., 2008). The programme was dedicated to Mahatma Gandhi, Father of the Nation, on his birthday, i.e., $2^{\text {nd }}$ of October 2010, since then this programme has been popularly known as Mahatma Gandhi National Rural Employment Guarantee Act (MGNREGA). This social welfare programme is primarily intended to enhance the livelihood securities of the people in rural areas by supplementing wage employment opportunities to the unskilled labor force. Therefore, it is considered as a "Silver Bullet" for eradicating rural poverty and unemployment, by way of generating demand for a productive labor force in villages.

The purpose of the article. The article aims to provide a conceptualized Research Model that can propose a framework on how to maintain sustainable rural employment opportunities for the people of rural India. The MGNREGA is an important segment of the Indian rural economy. It is indeed a landmark legislation in Indian history of social security legislation after it gained indepen- 
dence in 1947. After the successful enactment of this programme, there was a victory for the fully-fledged right to employment in rural India, particularly for women and aged men. The programme aims at fulfilling the needs of the rural masses by employing at least one member of the family. The main objective of MGNREGA was the creation of durable assets and strengthening the livelihood resource based on the rural poor. Some of the encouraging features of this programme are as follows: (i) generation of the slew of female employment (ii); enhancing greater economic security, higher farm wages, lower migration and building of infrastructure and so on.

The Mahatma Gandhi National Rural Employment Guarantee Scheme (MGNREGS) primary objective is to augment the wage employment and its auxiliary objective is to strengthen natural resource management through works that address causes of chronic poverty like drought, deforestation, soil erosion, etc., and thus encourage sustainable development.

Analysis of recent studies and publications. Since the date of its implementation, many social scientists attempted to study the impact of the Programme and also its implementation procedures. Sen et al. (2009) attempted to measure the outcome of good governance practised by Gram Panchayats (GPs) of the West Medinipur district of West Bengal through the employment generated under NREGS. Data regarding different parameters such as transparency, accountability, effectiveness and efficiency, equity was taken into consideration in this study.

Khan, Ullah and Salluja (2007) have discussed the direct and the indirect effects of NREGS on employment generation and poverty reduction in a local area. For this, a detailed survey was done in a poor agricultural village with 400 households, nearly 2500 people.

Dey and Bedi (2010) studied the functioning of the NREGA between February 2006 and July 2009 in Birubham district, West Bengal. This study shows that, in Birubham, there was a great awareness about the NREGA in rural areas.

Nayak, Behera, and Mishra (2008) conducted their study in 2 districts of Orissa, mainly Mayurbhanj and Balasore. NREGA programme was first introduced in 200 most underdeveloped districts of the country.

Mathur (2007) alluded that a system of a regular and continuous flow of authoritative information is essential for NREGS government officials, panchayat functionaries, elected representatives, NGOs and community groups.

Mathur (2009) states that in a social audit undertaken in Andhra Pradesh, it was found that in certain villages, some people revealed that they had not been paid for the work done, which led to financial irregularities of Rs. 50,000.

The scientific novelty of the article. It is the biggest poverty alleviation programme in the world, which started with an initial outlay of Rs. 11,300 crore in 2006-2007 and then increased to Rs. 40,000 crore in 2010-2011. The Act provides a legal guarantee of employment for 100 days in every financial year to adult 
members (at least one in a family) of any rural household that will do public work-related unskilled manual work at the statutory minimum wage. This minimum wage varies from state to state, in some states it is Rs. 80 whereas in others it is Rs. 125 or Rs. 120. According to the Act, the minimum wage cannot be less than Rs. 60. The 100 days of work was estimated because the agricultural sector does not employ people throughout the year. Therefore, unskilled workers have no alternative source of income for the remainder of the year.

The other key attributes of this scheme are a time-bound guarantee, laborintensive work, decentralised participatory planning, women's empowerment, worksite facilities and, above all, transparency and accountability through the provision of social audits and right to information. There is an effort to separate payment agencies from implementing agencies, thereby preventing embezzlement of wages (Vanaik and Siddhartha, 2008).

MGNREGP, which has been adopted in India as a strategy of inclusive growth, is alleged to have several shortcomings. Though its effective and fair implementation at the grass-root level may bring social equity and strengthen the income resource base of the poor, the fruits of its implementation are yet to be realized. The benefits of the program to the non-poor instead of the poor can exercise the former's economic power and contribute to the campaign funds of the major political parties in exchange for preferential treatment in welfare services (Jha et al., 2009).

Research methods and data. Nine dimensions are framed for this study. These are: i) Providing Employment Opportunity, ii) Plan Working and Administrative Management, iii) Minimum Wage Awareness, iv) Social Development, v) Banking Services and Utility, vi) Health and Insurance, vii) Poverty Eradication, viii) Children Education and Health, and ix) Economic Development. Here Demographic variables Providing Employment Opportunity, Plan Working and Administrative Management, Minimum Wage Awareness, Social Development, Banking Services, Health and Insurance, Children Education and Health are independent variables, and Poverty Eradication and Economic Development are the dependent variable. The article investigates how and to what extent the independent variables make changes in the dependent variable. The proposed conceptual research model shows the process of research as follows: (Fig. 1).

The research employed a cross-sectional methodological approach. The methodology described as cross-sectional "is one used to collect data on all relevant variables at one time" (O'Sullivan and Rassel, 1999). This approach is particularly useful for studies designed to collect information on attitudes and behaviors of large geographically diverse populations (O’Sullivan and Rassel, 1999).

Surveys generally fall into one of two categories, descriptive or relational. Descriptive surveys are designed to provide a snapshot of the current state of affairs, while relational surveys are designed to empirically examine relationships among two or more constructs either in an exploratory or in a confirmatory 


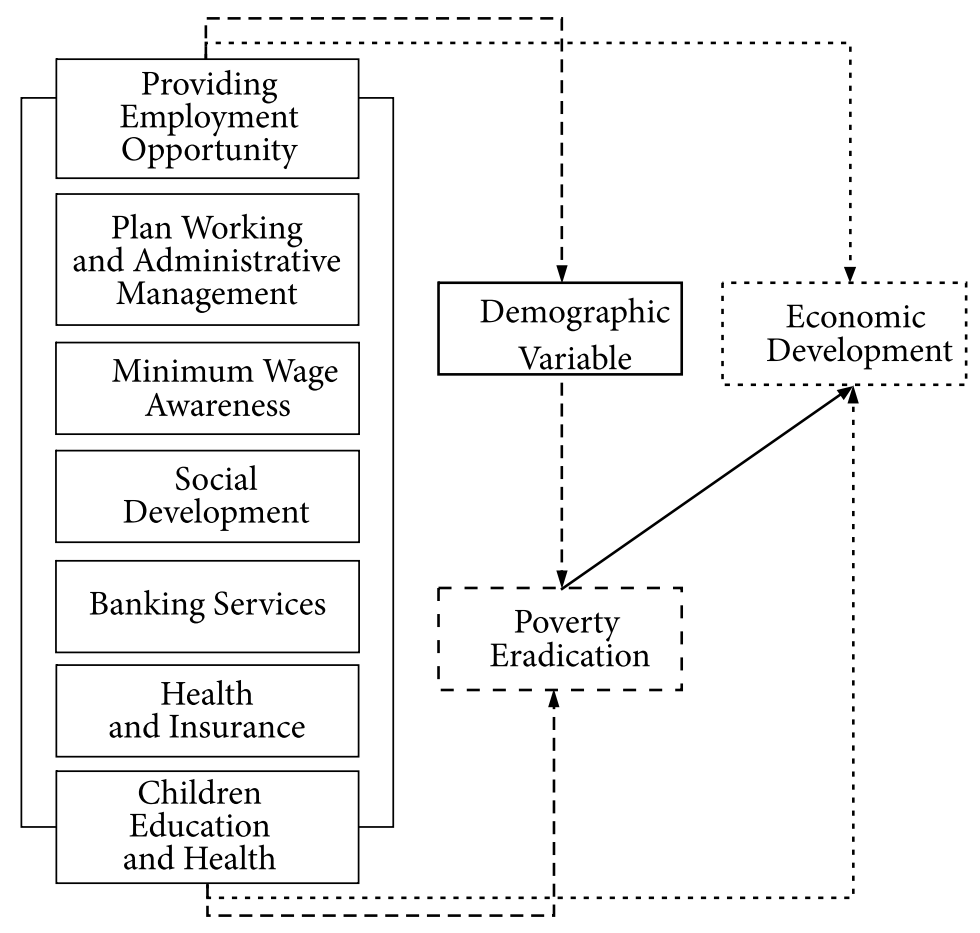

Fig. 1. Conceptual Model for studying Mahatma Gandhi National Rural Employment Guarantee Programme in Rural India Source: Authors' own creation.

manner. The current study is a relational survey that seeks to explore the relationship between Providing Employment Opportunities (E), Plan Working and Administrative Management (AM), Minimum Wage Awareness (MW), Social Development (SD), Banking Services (BS), Health and Insurance (HI), Poverty Eradication (PE), Children Education and Health (CEH), and Economic Development (ED) on the Mahatma Gandhi National Rural Employment Guarantee Programme.

Construct Measures and Data Collection. Data were collected by means of a structured questionnaire comprising nine marked dimensions. Providing Employment Opportunities consists of six questions, Plan Working and Administrative Management consists of six questions, Minimum Wage Awareness consists of seven questions, Social Development consists of seven questions, Banking Services consists of four questions, Health and Insurance consists of five questions, Poverty Eradication consists of five questions, Children Education and Health consists of four questions, and Economic Development consists of six questions. Finally, demographic profile information was given in the ten questions about respondents. All the dimensions were presented as statements on the questionnaire, with the same rating scale used throughout and measured on 
a seven-point, Likert-type scale that varied from 1 highly dissatisfied to 7 highly satisfied and Strongly Disagree to Strongly Agree. For conducting an empirical study, data were collected from respondents in the Wetland area and Dryland area in Rural India. Assurance was given to the respondents that the information collected from them will be kept confidential and will be used only for academic research purposes.

Stratified sampling was the sampling procedure used for the study. The stratification has been done based on the Taluks are Kumbakonam (Thanjavur District), Keeranur (Pudukottai District) and Nagappatinam (Nagappatinam District) for the nature of region south, east, centre, west and north while selecting the MGNREGP Employees from each category, non-probabilistic convenience and judgmental sampling technique was used. However, within such District, the respondents were selected by stratified random sampling. The data collected were analyzed for the entire sample (also see IIT, Madras, 2009).

Procedure for Data Analysis. The data collected were analyzed for the entire sample. Data analyses were performed with Statistical Package for Social Sciences (SPSS) using techniques that included descriptive statistics, Correlation analysis and Analysis of Moment Structures (AMOS) package for Structural Equation Modelling and Bayesian estimation and testing.

Structural Equation Modelling. The main study used Structural Equation Modelling because of two advantages: "(1) Estimation of Multiple and Interrelated Dependence Relationships, and (2) The Ability to Represent Unobserved Concepts in These Relationships and Account for Measurement Error in the Estimation Process" (Hair et al., 1998). Therefore, multiple regressions were simultaneously estimated; the direct and indirect effects were identified (Tate, 1998). However, a series of separate multiple regressions had to be established based on "theory, prior experience, and the research objectives to distinguish which independent variables predict each dependent variable" (Hair et al., 1998). In addition, because SEM considers a measurement error, the reliability of the predictor variable was improved. AMOS 7.0 (Arbuckle and Wothke, 2006), a computer program for formulating, fitting and testing Structural Equation Models (SEM) to observed data, was used for SEM, and the data preparation was conducted with SPSS 13.0.

Linear Structural Equation Models (SEMs) are widely used in sociology, econometrics, management, biology, and other sciences. A SEM (without free parameters) has two parts: a probability distribution (in the Normal case specified by a set of linear structural equations and a covariance matrix among the "error" or "disturbance" terms), and an associated path diagram corresponding to the causal relations among variables specified by the structural equations and the correlations among the error terms. It is often thought that the path diagram is nothing more than a heuristic device for illustrating the assumptions of the model. However, in this research study, we try to show how path 
diagrams can be used to solve several important problems in structural equation modelling.

Structural Equation Models with latent variables are more and more often used to analyze relationships among variables in marketing and consumer research (see for instance Bollen, 1989; Bentler, 1995; Schumacker and Lomax, 1996; Batista-Foguet and Coenders, 2000, for an introduction and Bagozzi, 1994 for applications to marketing research). Some reasons for the widespread use of these models are their parsimony (they belong to the family of linear models), their ability to model complex systems (where simultaneous and reciprocal relationships may be present, such as the relationship between quality and satisfaction), and their ability to model relationships among non-observable variables while taking measurement errors into account (which are usually sizeable in questionnaire data and can result in biased estimates if ignored).

As is usually recommended, a Confirmatory Factor Analysis (CFA) model is first specified to account for the measurement relationships from latent to observable variables. In our case, the latent variables are the four perception dimensions and the observed variables the 30 perception items. The relationships among latent variables cannot be tested until a well-fitting CFA model has been reached. In our case, the relationships among Mahatma Gandhi National Rural Employment Guarantee Programme (MGNREP), the mediating impact of Poverty Eradication with the E, AM, WA, SD, BS, HI, CEH and ED dimensions are of interest. This modelling sequence stresses the importance of the goodness of fit assessment. As a combination of regression, path and factor analyses, in SEM, each predictor is used with its associated uncontrolled error and, unlike regression analyses, predictor multi-collinearity does not affect the model results.

Bayesian Estimation and Testing in SEM. With modern computers and software, a Bayesian approach to structural equation modelling is now possible. Posterior distributions over the parameters of a structural equation model can be approximated to arbitrary precision with AMOS, even for small samples. Being able to compute the posterior over the parameters allows us to address several issues of practical interest. First, prior knowledge about the parameters may be incorporated into the modelling process in AMOS. Second, we need not rely on asymptotic theory when the sample size is small, a practice that is misleading for inference and goodness-of-fit tests in SEM (Boomsma, 1983). Third, the class of models that can be handled is no longer restricted to just identified or overidentified models. Whereas each identifying assumption must be taken as given in the classical approach, in a Bayesian approach some of these assumptions can be specified with perhaps more realistic uncertainty.

Regression Model of the "MGNREGP QUAL" Mediated Structural Model. In hierarchical regression, the predictor variables are entered in sets of variables according to a predetermined order that may infer some causal or potentially mediating relationships between the predictors and the dependent variable 


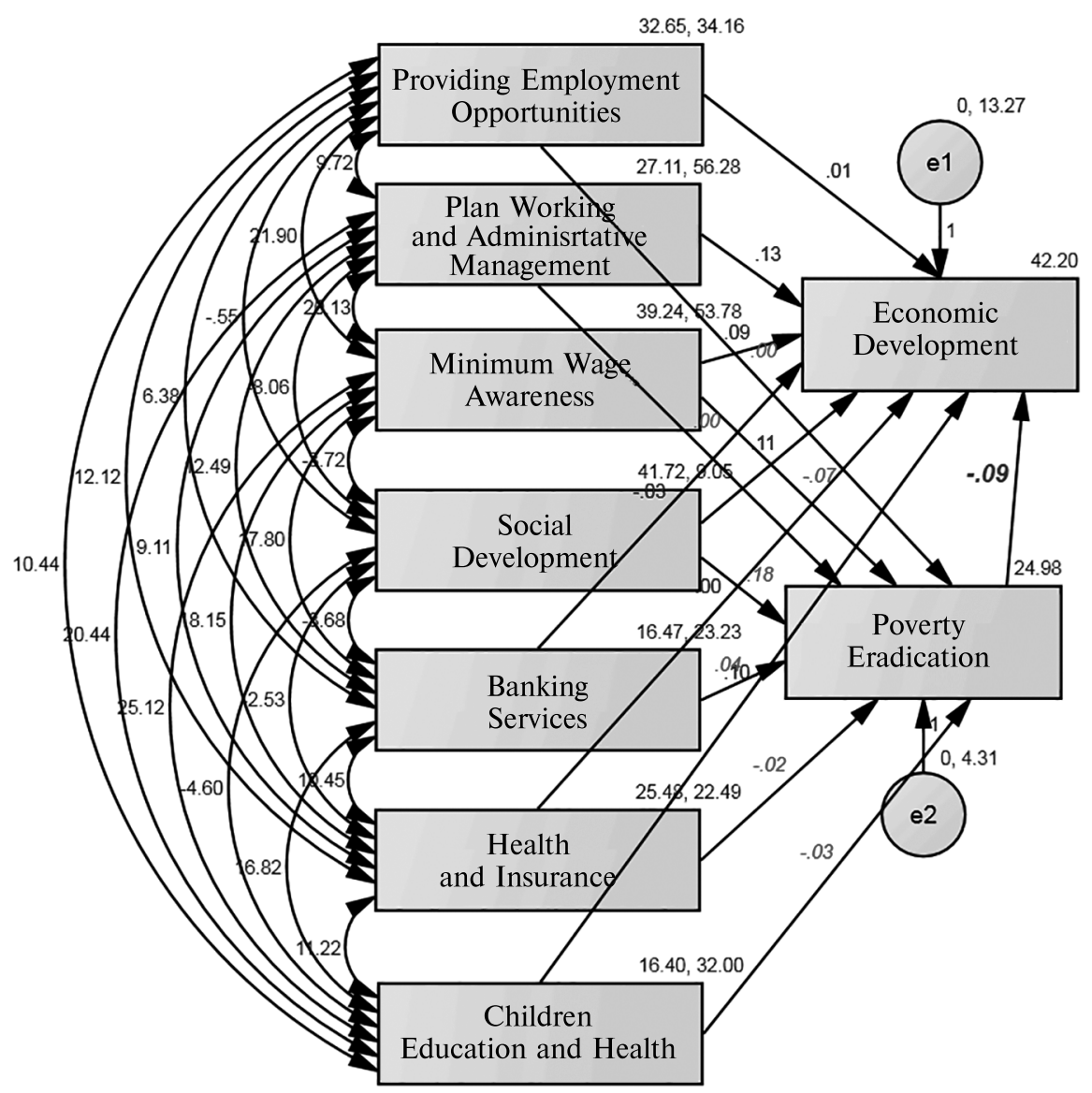

Fig. 2. Shows The AMOS Output with Regression Weights of "MGNREGP QUAL" Mediated Model

Source: Authors' own creation.

(Francis, 2003). Such situations are frequently of interest in the social sciences. The logic involved in hypothesizing mediating relationships is that "The Independent Variable Influences the Mediator Which, In Turn, Influences the Outcome" (Holmbeck, 1997). However, an important precondition for examining mediated relationships is that the independent variable is significantly associated with the dependent variable before testing any model for mediating variables (Holmbeck, 1997). Of interest is the extent to which the introduction of the hypothesized mediating variable reduces the magnitude of any direct influence of the independent variable on the dependent variable (Baron and Kenny, 1986). Hence the research report empirically tested the hierarchical regression for the model conceptualized in Figure 3 within the AMOS 20.0 graphics environment.

With the analyses conducted, the parameter estimates are then viewed within AMOS graphics and it displays the standardized parameter estimates. The regres- 
sion analysis revealed that the Poverty Eradication on the various dimensions of Economic Development (ED), Poverty Eradication (PE) influenced -0.09 of the Economic Development followed by Social Development (SD) which explains .18. The R2 value of -0.09 is displayed above the box Economic Development (ED) in the AMOS graphics output. The visual representation of results suggests that the relationships between the dimensions of Economic Development, Social Development $(\mathrm{SD})=>(\mathrm{PE})$ Poverty Eradication $=.18)$ resulted in a significant impact on the mediated factor 'Poverty Eradication. Providing Employment Opportunities (E), Plan Working and Administrative Management (AM), Minimum Wage Awareness (MW), Banking Services (BS), Children Education and Health $(\mathrm{CEH})$ resulted in very limited influence on the Poverty Eradication. It shows that the Poverty Eradication towards the Social Development (SD) and Health and Insurance (HI) towards the outcome of Economic Development (ED) is insignificant whereas the impact of the same is very high on mediating variable.

Bayesian Estimation and Testing for "MGNREGP QUAL" Mediated Structural Equation Model. The research model is an SEM, while many management scientists are most familiar with the estimation of these models using software

Table 1. Bayesian Convergence Distribution for "MGNREGP QUAL” Regression Model

\begin{tabular}{|l|c|c|c|c|c|c|c|c|c|}
\hline \multicolumn{7}{|c|}{ Regression Weights } \\
\hline & Mean & S.E. & S.D. & C.S. & Skewness & Kurtosis & Min & Max & Name \\
\hline PE<-E & -0.004 & 0.000 & 0.016 & 1.000 & -0.047 & 0.010 & -0.067 & 0.065 & W1 \\
PE<-M & 0.002 & 0.000 & 0.012 & 1.000 & 0.027 & -0.025 & -0.044 & 0.053 & W2 \\
PE<-W & -0.068 & 0.000 & 0.015 & 1.000 & -0.014 & -0.032 & -0.123 & 0.000 & W3 \\
PE<-SD & 0.185 & 0.001 & 0.027 & 1.000 & -0.078 & 0.017 & 0.062 & 0.290 & W4 \\
PE<-BS & 0.036 & 0.001 & 0.021 & 1.000 & -0.046 & -0.064 & -0.052 & 0.132 & W5 \\
PE<-HI & -0.017 & 0.000 & 0.021 & 1.000 & 0.027 & 0.020 & -0.107 & 0.074 & W6 \\
PE<-CEH & -0.026 & 0.001 & 0.02 & 1.000 & 0.041 & 0.021 & -0.113 & 0.055 & W7 \\
ED<-PE & 0.254 & 0.001 & 0.066 & 1.000 & -0.026 & 0.013 & 0.547 & 0.033 & W8 \\
\hline \multicolumn{70}{|c|}{} & \multicolumn{7}{|c|}{ Means } & & & \\
\hline & Mean & S.E. & S.D. & C.S. & Skewness & Kurtosis & Min & Max & Name \\
\hline E & 32.658 & 0.006 & 0.220 & 1.000 & 0.014 & 0.127 & 31.710 & 33.574 & M1 \\
AM & 27.110 & 0.006 & 0.281 & 1.000 & -0.004 & 0.051 & 25.961 & 28.392 & M2 \\
MW & 39.239 & 0.007 & 0.277 & 1.000 & 0.031 & 0.034 & 38.169 & 40.401 & M3 \\
SD & 41.713 & 0.003 & 0.112 & 1.000 & -0.043 & 0.038 & 41.233 & 42.191 & M4 \\
BS & 16.472 & 0.005 & 0.180 & 1.000 & -0.030 & -0.052 & 15.724 & 17.135 & M5 \\
HI & 25.483 & 0.003 & 0.174 & 1.000 & 0.030 & -0.074 & 24.802 & 26.142 & M6 \\
CEH & 16.394 & 0.005 & 0.214 & 1.000 & 0.044 & -0.005 & 15.589 & 17.303 & M7 \\
\hline
\end{tabular}


End of the table 1

\begin{tabular}{|c|c|c|c|c|c|c|c|c|c|}
\hline \multicolumn{10}{|c|}{ Intercepts } \\
\hline & Mean & S.E. & S.D. & C.S. & Skewness & Kurtosis & Min & Max & Name \\
\hline PE & 25.001 & 0.024 & 1.358 & 1.000 & 0.056 & 0.015 & 19.034 & 30.693 & I1 \\
\hline ED & 59.996 & 0.044 & 1.953 & 1.000 & 0.020 & -0.024 & 51.435 & 68.677 & $\mathrm{I} 2$ \\
\hline \multicolumn{10}{|c|}{ Covariance's } \\
\hline & Mean & S.E. & S.D. & C.S. & Skewness & Kurtosis & Min & $\operatorname{Max}$ & Name \\
\hline $\mathrm{E}<->\mathrm{CEH}$ & 10.661 & 0.032 & 1.299 & 1.000 & 0.087 & -0.030 & 5.651 & 15.690 & $\mathrm{C} 1$ \\
\hline $\mathrm{AM}<->\mathrm{CEH}$ & 20.856 & 0.051 & 1.784 & 1.000 & 0.191 & 0.096 & 14.426 & 28.862 & $\mathrm{C} 2$ \\
\hline $\mathrm{MW}<->\mathrm{CEH}$ & 25.650 & 0.041 & 1.832 & 1.000 & 0.208 & 0.201 & 19.019 & 34.384 & C3 \\
\hline $\mathrm{SD}<->\mathrm{CEH}$ & -4.688 & 0.016 & 0.671 & 1.000 & -0.119 & -0.073 & -7.276 & -2.424 & $\mathrm{C} 4$ \\
\hline $\mathrm{BS}<->\mathrm{CEH}$ & 17.198 & 0.028 & 1.186 & 1.000 & 0.181 & 0.113 & 12.242 & 22.676 & C5 \\
\hline $\mathrm{HI}<->\mathrm{CEH}$ & 11.467 & 0.028 & 1.091 & 1.000 & 0.100 & 0.051 & 7.186 & 16.067 & C6 \\
\hline $\mathrm{E}<->\mathrm{HI}$ & 12.383 & 0.030 & 1.166 & 1.000 & 0.161 & 0.097 & 7.963 & 17.694 & C7 \\
\hline $\mathrm{AM}<->\mathrm{HI}$ & 9.341 & 0.040 & 1.385 & 1.000 & 0.121 & 0.094 & 3.822 & 15.455 & $\mathrm{C} 8$ \\
\hline $\mathrm{MW}<->\mathrm{HI}$ & 18.538 & 0.045 & 1.506 & 1.000 & 0.177 & 0.081 & 12.736 & 24.559 & C9 \\
\hline $\mathrm{SD}<->\mathrm{HI}$ & -2.585 & 0.013 & 0.545 & 1.000 & -0.091 & 0.047 & -4.936 & -0.345 & C10 \\
\hline $\mathrm{BS}<->\mathrm{HI}$ & 10.695 & 0.023 & 0.951 & 1.000 & 0.236 & 0.167 & 7.171 & 14.956 & C11 \\
\hline $\mathrm{E}<->\mathrm{BS}$ & 6.503 & 0.028 & 1.076 & 1.000 & 0.056 & 0.009 & 2.643 & 10.769 & $\mathrm{C} 12$ \\
\hline $\mathrm{AM}<->\mathrm{BS}$ & 12.776 & 0.034 & 1.440 & 1.000 & 0.229 & 0.197 & 7.134 & 19.458 & C13 \\
\hline $\mathrm{MW}<->\mathrm{BS}$ & 18.194 & 0.037 & 1.492 & 1.000 & 0.195 & 0.122 & 12.072 & 24.152 & C14 \\
\hline $\mathrm{SD}<->\mathrm{BS}$ & -3.746 & 0.012 & 0.567 & 1.000 & -0.098 & 0.051 & -6.308 & -1.556 & C15 \\
\hline $\mathrm{MW}<->\mathrm{SD}$ & -3.773 & 0.022 & 0.834 & 1.000 & -0.124 & 0.088 & -7.337 & -0.750 & C16 \\
\hline $\mathrm{AM}<->\mathrm{SD}$ & -8.257 & 0.020 & 0.909 & 1.000 & -0.143 & 0.133 & -12.595 & -5.188 & C17 \\
\hline $\mathrm{E}<->\mathrm{SD}$ & -0.565 & 0.017 & 0.655 & 1.000 & -0.095 & 0.009 & -3.402 & 1.893 & C18 \\
\hline $\mathrm{E}<->\mathrm{MW}$ & 22.369 & 0.033 & 1.837 & 1.000 & 0.179 & 0.122 & 15.225 & 31.264 & C19 \\
\hline $\mathrm{E}<->\mathrm{AM}$ & 9.975 & 0.044 & 1.707 & 1.000 & 0.129 & 0.036 & 2.877 & 18.365 & C20 \\
\hline $\mathrm{AM}<->\mathrm{MW}$ & 20.586 & 0.060 & 2.212 & 1.000 & 0.132 & 0.058 & 12.548 & 30.960 & C21 \\
\hline \multicolumn{10}{|c|}{ Variances } \\
\hline & Mean & S.E. & S.D. & C.S. & Skewness & Kurtosis & Min & Max & Name \\
\hline $\mathrm{E}$ & 34.942 & 0.042 & 1.849 & 1.000 & 0.218 & 0.002 & 28.786 & 44.888 & V1 \\
\hline $\mathrm{AM}$ & 57.608 & 0.075 & 3.033 & 1.000 & 0.216 & -0.005 & 47.142 & 71.453 & V2 \\
\hline MW & 54.932 & 0.070 & 2.884 & 1.000 & 0.196 & 0.124 & 44.423 & 68.260 & V3 \\
\hline SD & 9.273 & 0.011 & 0.499 & 1.000 & 0.272 & 0.103 & 7.538 & 11.401 & V4 \\
\hline BS & 23.771 & 0.031 & 1.235 & 1.000 & 0.192 & 0.056 & 19.179 & 28.976 & V5 \\
\hline $\mathrm{HI}$ & 22.966 & 0.039 & 1.225 & 1.001 & 0.207 & 0.010 & 18.644 & 28.298 & V6 \\
\hline $\mathrm{CEH}$ & 32.687 & 0.030 & 1.704 & 1.000 & 0.206 & 0.093 & 26.654 & 39.721 & V7 \\
\hline e2 & 4.380 & 0.004 & 0.232 & 1.000 & 0.266 & 0.229 & 3.538 & 5.683 & V8 \\
\hline e1 & 15.851 & 0.022 & 0.824 & 1.000 & 0.167 & 0.033 & 12.981 & 19.709 & V9 \\
\hline
\end{tabular}

Source: Authors' own calculation using Amos output 20.0 
that analyses covariance matrix of the observed data (e.g. LISREL, AMOS, EQS), the research report adopts a Bayesian approach for estimation and inference in AMOS 20.0 environment (Senthilkumar and Arulraj, 2011; Arbuckle and Wothke, 2006). Since it offers numerous methodological and substantive advantages over alternative approaches.

Posterior Diagnostic Plots of 'MGNREGP QUAL' Mediated Regression Model. To check the convergence of the Bayesian MCMC method, the posterior diagnostic plots are analyzed. Figure 4 shows the posterior frequency polygon of the distribution of the parameters across the 78000 samples. The Bayesian MCMC diagnostic plots reveals that for all the figures the normality is achieved, so the structural equation model fit is accurately estimated.

The trace plot also called as time-series plot shows the sampled values of a parameter over time. This plot helps to judge how quickly the MCMC procedure converges in distribution. Figure 5 shows the trace plot of the mediated MGNREGP QUAL model for the mediated factor Poverty Eradication Economic Development dimension across samples. If we mentally break up this plot into a few horizontal sections, the trace within any section would not look much different from the trace in any other section. This indicates that the convergence in

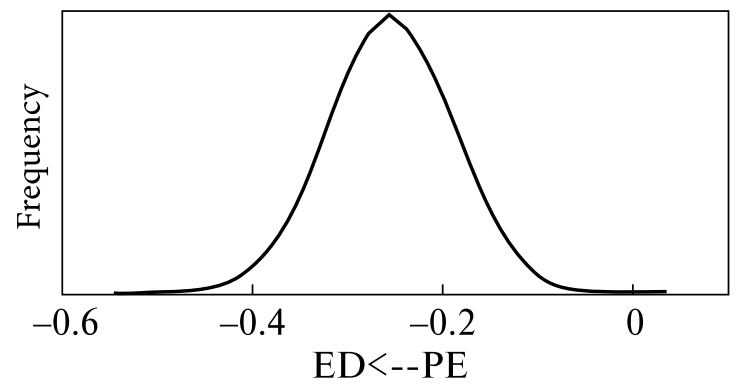

Fig. 3. Posterior frequency polygon distribution of the Mediating Factor Economic Development and Poverty Eradication Source: Authors' own creation.

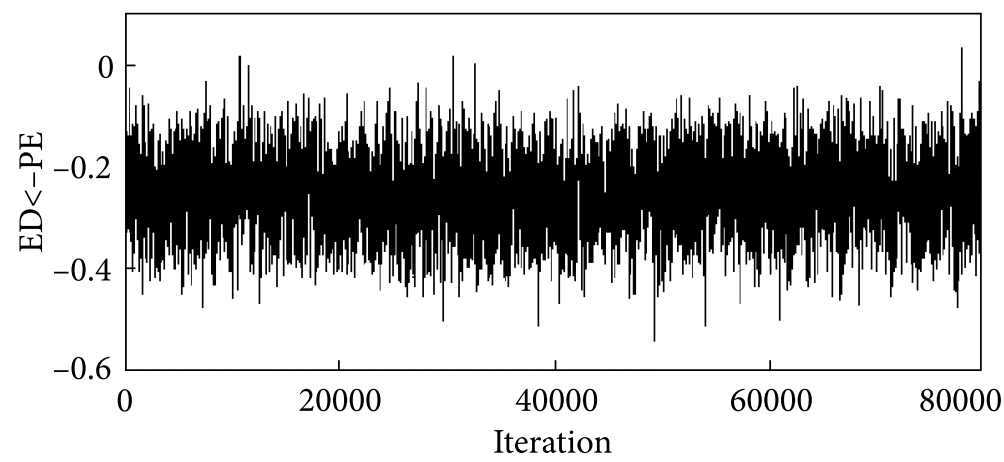

Fig. 4. Posterior trace plot of the MGNREGP QUAL Regression Model for the Mediated Factor Economic Development and Poverty Eradication Source: Authors' own creation. 


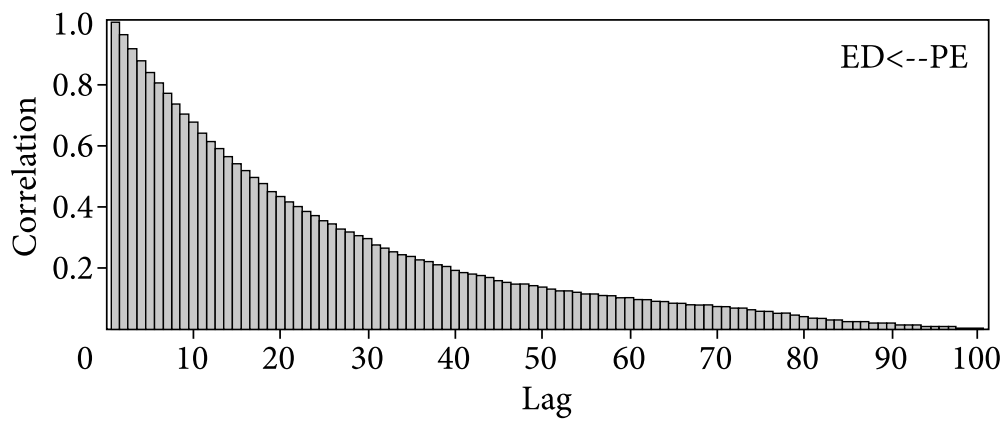

Fig. 5. Posterior correlation plot of the MGNREGP QUAL Regression Model for the Mediated Factor Economic Development and Poverty Eradication

Source: Authors' own creation.

distribution takes place rapidly. Hence the mediated MGNREGP QUAL MCMC procedure very quickly forgets its starting values.

To determine how long it takes for the correlations among the samples to die down, an autocorrelation plot which is the estimated correlation between the sampled value at any iteration and the sampled value $\mathrm{k}$ iterations later for $\mathrm{k}=1$, $2,3, \ldots$ is analyzed for the MGNREGP QUAL regression model. Figure 6 shows the correlation plot of the MGNREGP QUAL model for the mediated factor Poverty Eradication to Economic Development dimension across samples. The figure exhibits that at lag 100 and beyond, the correlation is effectively 0 . This indicates that by 90 iterations, the MCMC procedure has essentially forgotten its starting position. Forgetting the starting position is equivalent to convergence in distribution. Hence it is ensured that convergence in distribution was attained and that the analysed samples are indeed samples from the true posterior distribution.

Even though marginal posterior distributions are very important, they do not reveal relationships that may exist among the two parameters. The frequency polygons given in the figure 4 describes only the marginal posterior distributions of the parameters.

Figure 7 displays the two-dimensional plot of the bivariate posterior density across 78000 samples. Ranging from dark to light, the three shades of gray represent $50 \%, 90 \%$ and $95 \%$ credible regions, respectively. From the figure it is revealed that the sample respondent's responses are normally distributed.

Fig. 6. Two-dimensional plot of the bivariate posterior density for the Regression Weights Social Development to Poverty Eradication and Economic Development Source: Authors' own creation.

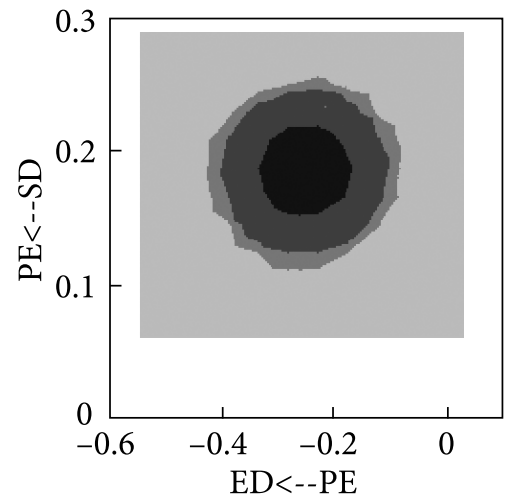


Mediated Model for Poverty Reduction in MGNREGP in the Wetland area and Dryland area in Rural India

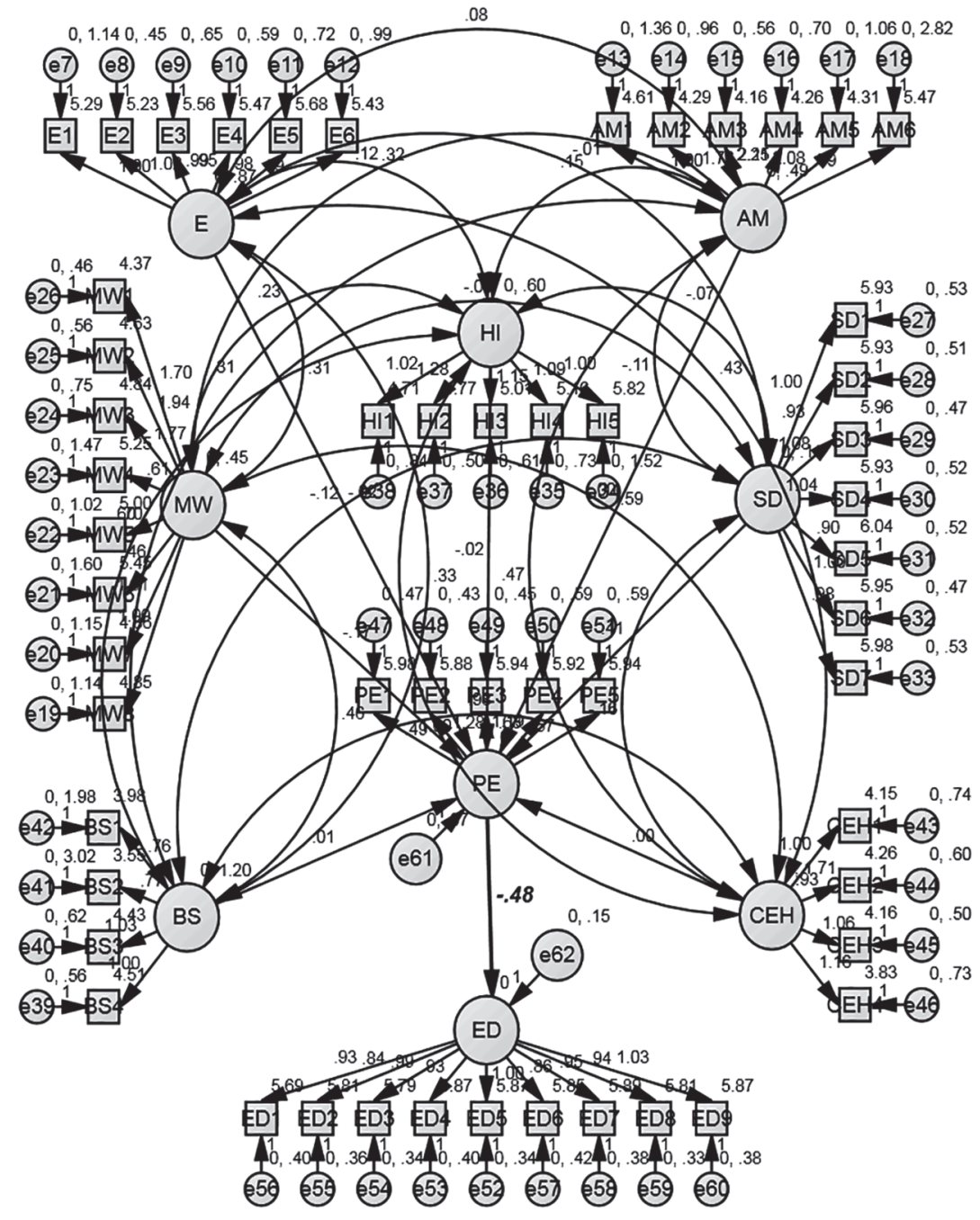

Fig. 7. Shows AMOS path diagram output for the overall MGNREGP QUAL Structural Equation Model

Source: Authors' own creation.

The various diagnostic plots featured from Figure 4 to Figure 7 of the Bayesian estimation of convergence of the MCMC algorithm confirms the fact that the convergence takes place and the normality is attained. Hence, the absolute fit of the MGNREGP QUAL Regression Model. From the MGNREGP QUAL regression model, which is empirically tested with mediated factor Poverty Eradication with dimensions of Social Development, and the Economic Development (ED), 
it is evident that the Mahatma Gandhi National Rural Employment Guarantee Programme should concentrate on the Poverty Eradication (PE) as the mandatory aspect of Mahatma Gandhi National Rural Employment Guarantee Programme in the Wetland area and Dryland area in Rural India, India. The overall regressed model statistically proved that the poverty reduction is mediated effects on the economic development process in the above-stated programme in India.

\section{Structural Equation Modeling of "MGNREGP QUAL" Mediated Mo-} del. Since the Economic Development in MGNREGP is a theoretical construct, the research study has defined its dimension based on the setting used to explore the construct. If Mediated "MGNREGP QUAL" Model is to be applicable in the Indian context, the dimensions and the sub-dimensions on Economic Development have to be reliable and valid in measuring Economic Development in the MGNREGP. The model examines the relative importance of dimensions of Economic Development and Poverty Eradication in Mahatma Gandhi National Rural Employment Guarantee Programme in the Wetland area and Dryland area in Rural India.

Figure 8 shows AMOS's path diagram output for the Overall MGNREGP QUAL Structural Equation Model. You can see that the Providing Employment Opportunities (E) dimension consists of 6 sub-dimension, Plan Working and Administrative Management (AM) dimension consists of 6 sub-dimensions, Minimum Wage Awareness (MW) dimension consists of 7 sub-dimensions, Social Development (SD) dimension consists of 7 sub-dimensions, Banking Services (BS) dimension consists of 4 sub-dimensions, Health and Insurance (HI) dimension consists of 5 sub-dimensions, Poverty Eradication (PE) dimension consists of 5 sub-dimensions, Children Education and Health (CEH) dimension consists of 4 sub-dimensions, and Economic Development (ED) dimension consists of 6 sub-dimensions. The RMSEA fit statistics for the model was 0.05, which was considered as a best-fit model (Browne and Cudeck, 1993; Diamantopoulos and Siguaw, 2000). The sampling distribution for the RMSEA can be derived, which makes it possible to compute confidence intervals. These intervals allow research reports to test for a close fit and not only for an exact fit, as the X2 does. If both extremes of the confidence interval are below 0.05 , then the hypothesis of close fit is rejected in favour of the hypothesis of better than close fit. If both extremes of the confidence interval are above 0.05 , then the hypothesis of close fit is rejected in favour of the hypothesis of bad fit (Senthilkumar and Arulraj, 2011). The path diagram shows the Poverty Eradication is the Mediating factor for Economic Development. The regression coefficient -0.48 signifies the impact of mediating factor Poverty Eradication (PE) on the on the other dimensions towards Economic Development (ED) the Mahatma Gandhi National Rural Employment Guarantee Programme.

Main results of the research. This research has adopted the procedure of assessing convergence of MCMC algorithm of maximum likelihood. To estimate 


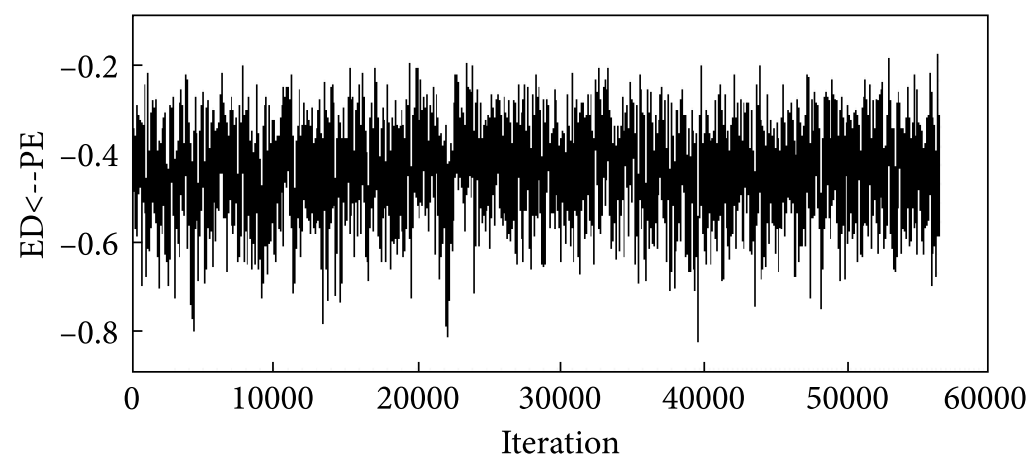

Fig. 8. Posterior trace plot of the MGNREGP QUAL Medicated model for the mediated factor Economic Development (ED) and Poverty Eradication

Source: Authors' own creation.

the MCMC convergence, the research report has adopted two methods, namely convergence in distribution, the convergence of posterior summaries. The values of the posterior mean accurately estimate the MGNGREGP QUAL mediated SEM model. The highest value of Convergence Statistics (C.S) is 1.001 which is less than the 1.002 conservative measures (Gelman et al., 2004).

The trace plot shows the sampled values of a parameter over time. This plot helps to judge how quickly the MCMC procedure converges in distribution. The following figure 9 shows the trace plot of the mediated MGNREGP QUAL model for the mediated factor Poverty Eradication with Economic Development dimension across 57000 samples. If we mentally break up this plot into a few horizontal sections, the trace within any section would not look much different from the trace in any other section. This indicates that the convergence in distri bution takes place rapidly. Hence, the mediated MGNREGP QUAL MCMC procedure very quickly forgets its starting values.

To determine how long it takes for the correlations among the samples to die down, an autocorrelation plot which is the estimated correlation between the sampled value at any iteration and the sampled value $\mathrm{k}$ iterations later for $\mathrm{k}=1,2,3, \ldots$ is analysed for the MGNREGP QUAL regression model. Figure 10 shows the correlation plot of the MGNREGP QUAL model for the mediated factor Poverty Eradication with Economic Development dimension across 57000 samples. The figure exhibits that at lag 100 and beyond, the correlation is effectively 0 . This indicates that by 90 iterations, the MCMC procedure has essentially forgotten its starting position. Forgetting the starting position is equivalent to convergence in distribution. Hence it is ensured that convergence in distribution was attained and that the analysis samples are indeed samples from the true posterior distribution.

Economical Implication. From this empirical analysis, the research identified that Poverty Reduction and Economic Development is the Moderating or 


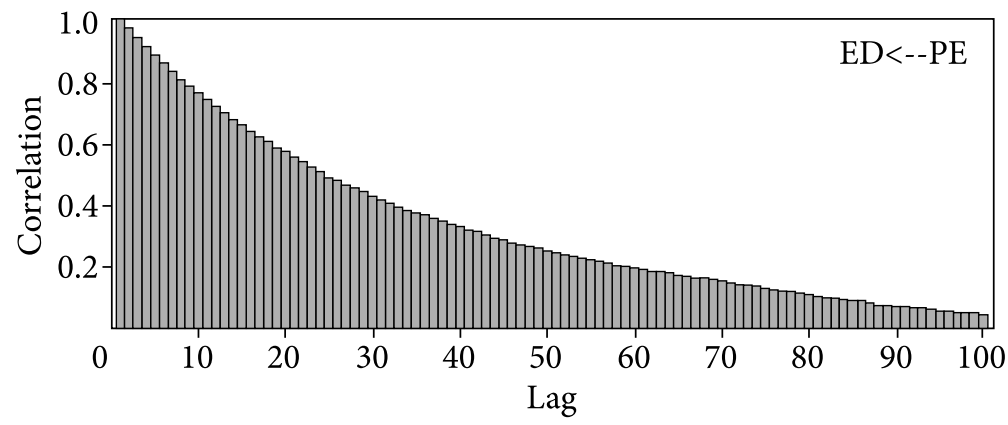

Fig. 9. Posterior correlation plot of the MGNREGP QUAL Mediated model for the mediated factor Economic Development and Poverty Eradication

Source: Authors' own creation.

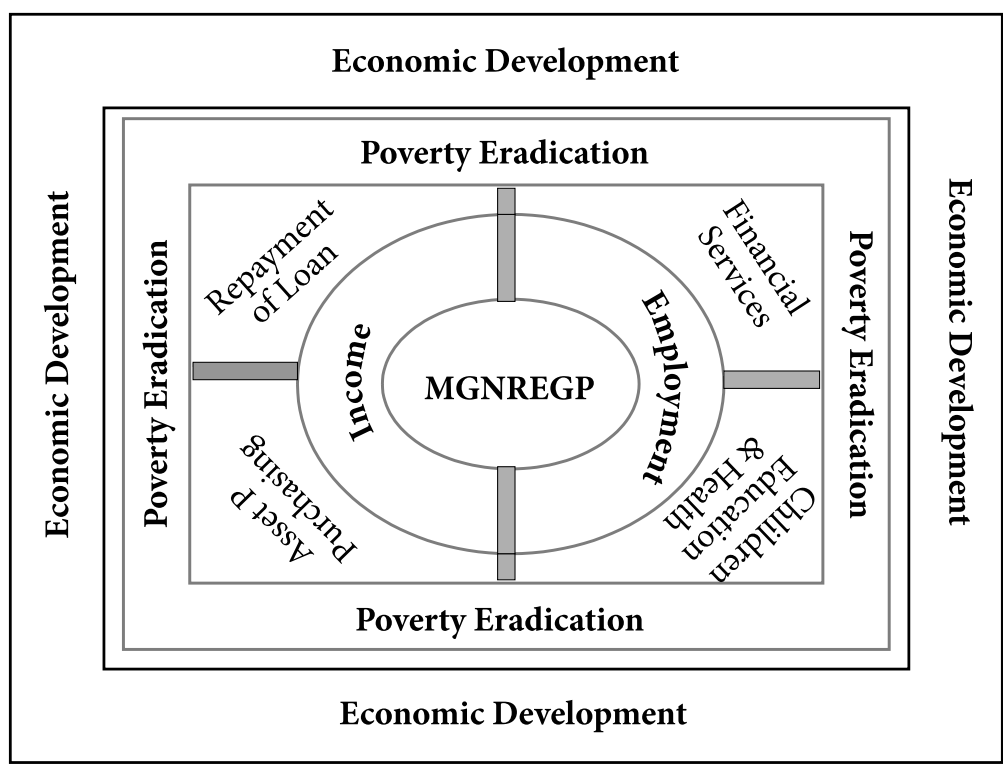

Fig. 10. Strategic Economic Planning for the Mahatma Gandhi National Rural Employment Guarantee Programme

Source: Authors' own creation.

most influential dimension for the MGNREGP at Wetland area and Dryland Area in Rural India.

Interestingly, three dimensions are negatively influenced by the resulting dimension MGNREGP they are Wage Awareness (-0.38). But all the dimensions of MGNREGP Model are positively associated with the Moderated dimensions of Poverty Reduction and Economic Development.

In India, the Mahatma Gandhi National Rural Employment Guarantee Programme faces the challenge of employing a broad range of beneficiaries. Thus, 
what appears from the critical examination of some of the poverty alleviation programmes is that the various rural development programmes have achieved expected development and may have been very little progress. It is a continuous process. Although rural poverty cannot be eliminated immediately, continuous efforts should be made to develop the rural areas on a priority basis. The crux of the problem is that the rural poor have to be further organized and motivated on an on-going basis to improve their living conditions. See figure 11 for more understanding.

Conclusion. In this article we provided a conceptualized research model that can offer a framework on how to maintain sustainable development in rural India through the MGNREGP. MGNREGP is the ultimate employment generating scheme for reducing the poverty in a rural area and sustainability common resource property in a village of India. Hence, the MGNREGA is considered as a "Silver Bullet" for eradicating rural poverty and unemployment, by way of generating demand for a productive labor force in villages. MGNREGA is distinctive for its unique vision to redefine avenues of providing employment opportunities to the deprived in rural India. But the possibility and efficient chances of employment largely come with a better level of awareness as it marks the level of accessibility. It thus necessitates sufficient awareness amongst the intended beneficiaries regarding provisions like guaranteed days of employment, unemployment allowance, minimum wages, availability of complaint register, etc. As most of the worker respondents are illiterate and belong to the economically poor class, the extent of awareness about NREGA has emerged out to be a major concern in all the hamlets. The procedural and implementation aspects of NREGA have never been free from confronting some basic challenges like general awareness, understanding policy nitty-gritty, sufficient access etc.

Given the socioeconomic background of the respondents, the structural issues such as transparency, maintenance of documents and accountability were difficult things to actualize from the workers' point of view. Above stated models is more correlated to economic development in the study area. Nevertheless, poverty could be reduced by providing employment opportunities for rural India.

MGNREGA is a landmark legislation in the history of social security legislation in India after independence. Enacted after a successful struggle for a comprehensive employment guarantee law, this legislation is a partial victory towards a full-fledged right to employment. Though MGNREGA is well-thought-out legislation, a powerful tool in the hands of the common people to get their basic livelihood, its poor execution deprives the rural poor of their basic rights. The study reveals that despite numerous problems, MGNREGA is a program that has begun to make a difference in the lives of women. For example, women have started asserting their voices in family matters and the nature of spending money. Though awareness continues to be a stiff challenge, women in the study area have become pro-active learners and participants in the schemes. 
We conclude that the MGNREGP creates a right-based framework for wage employment programmes, by conferring legal entitlements and the right to demand employment upon the workers and makes the Government accountable for employing in a time-bound manner. In recent years, the delta districts of fertile lands have been converting to housing plots and landlords have introduced highly technical aspects to the agricultural process. Above causes unemployment burden to the rural side laborers such as landless laborers and artisans. All the causes of unemployment are abolished in rural delta districts in Tamilnadu through the MGNREGP.

\section{REFERENCES}

1. Ambasta, P., Shankar, P. S., \& Shah, M. V. (2008). Two Years of NREGA: The Road Ahead. Economic and Political Weekly, 43 (8): 41-50.

2. Arbuckle, J. L. \& Wothke, W. (2006). Amos 7.0 user's Guide. Chicago: Small Waters Corporation.

3. Bagozzi, R. P. (1994). Structural equation models in marketing research: basic principles R. P. Bagozzi (Ed.): Principles of Marketing Research. Cambridge: Basil Blackwell, 317-385.

4. Baron, R. M., \& Kenny, D. A. (1986). The Moderator-Mediator Variable Distinction in Social Psychological Research: Conceptual, Strategic, and Statistical. Journal of Personality and Social Psychology, 51 (6):1173-1182.

5. Batista-Foguet, J. M. \& Coenders, G. (2000). Modelos de Ecuaciones Estructurales [Structural Equation Models]. Madrid, Spain: La Muralla.

6. Bentler, P. M. (1995). EQS: Structural equations program manual. Encino, CA: Multivariate Software, Inc.

7. Bollen, K. A. (1989). Structural Equations with Latent Variables. New York: Wiley.

8. Boomsma, A. (1983). On the robustness of LISREL (maximum likelihood estimation against small sample size and non-normality. Amsterdam: Socio-metric Research Foundation, (Doctoral dissertation, University of Groningen, The Netherlands).

9. Browne, M. W., \& Cudeck, R. (1993). Alternative ways of assessing model fit. In K.A. Bollen and J.S. Long (Eds.): Testing Structural Equation Models. Thousand Oaks: Sage, 136-162.

10. Dey, S., \& Bedi, A. (2010). The National Rural Employment Guarantee Scheme in Birbhum. Economic and Political Weekly, XLV (41).

11. Diamantopoulos, A., \& Siguaw, J. A. (2000). Introducing LISREL. Sage, London.

12. Francis, G. (2003). Multiple Regression: Swinburne University Press. Frankel, F.R. India’s Political Economy, 1947-77. OUP. Delhi. 1977.

13. Gelman, A., Carlin, J. B., Stern, H. S., \& Rubin, D. B. (2004). Bayesian Data Analysis”, 2nd ed. Boca Raton: Chapman and Hall/CRC.

14. Hair, J. F., Anderson, R. E, Tatham, R. L. \& Black, W. C. (1998). Multivariate Date Analysis International Edition, 5th ed. N. J.: Prentice-Hall, New Jersey.

15. Holmbeck, G. N. (1997). Toward terminological, conceptual, and statistical clarity in the study of mediators and moderators: Examples from the child-clinical and pediatric psychology literatures. Journal of Consulting and Clinical Psychology, 4, 599-610.

16. Indian Institute of Technology, Madras, Chennai (2009). Evaluation of National Rural Employment Guarantee Act: In Districts: Cuddlore, Dindugal, Kanchipuram, Nagai, Thiruvalallur: State: TamilNadu, May. 
17. Jha, R., Bhattacharya, S., Gaiha, R., \& Shankar, S. (2009). Capture' of Anti-Poverty Programs: An Analysis of the National Rural Employment Guarantee Program in India. Journal of Asian Economics, 20 (4): 456-464.

18. Khan, A. U., \& Saluja, M. R. (2007). Impact of MNREGA on Rural Livelihoods, Paper Presented in $10^{\text {th }}$

19. Mathur, L. (2007). Employment Guarantee: Progress So Far. Economic and Political Weekly, 42 (52), 17-20.

20. Mathur, L. (2009). Silent but successful initiative. The Hindu. 1st March.

21. Narayan, Chandra Nayak, Bhagirath, Behera, \& Pulak, Mishra (2008). Appraisal of Processes and Procedures of NREGS in Orissa: A Study of Mayurbhanj and Balasore District. Project Report. Indian Institute of Technology, Kharagpur.

22. O’Sullivan, E., \& Rassel, G. R. (1999). Research methods for Public Administrators, New York, NY: Longman.

23. Schumacker Randall E. \& Richard G. Lomax (1996). A Beginner's Guide to Structural Equation Modeling, Mahwah, NJ: Earlbaum Associates.

24. Sen, B., Narayan, D. \& Hull, K. (2009). Moving out of poverty in India: An overview. The promise of empowerment and democracy in India. Washington, DC: World Bank.

25. Senthilkumar, N. \& Arulraj, A. (2011). SQM-HEI determination of service quality measurement of higher education in India. Journal of Modelling in Management, 6 (1), 60-78.

26. Tate, R. (1998). An introduction to modelling outcomes in the behavioural and social sciences, Boston, MA: Pearson Custom Publishing.

27. Vanaik, Siddhartha, Anish. (2008). Bank Payments: End of Corruption in NERGA? Economic and Political Weekly, April 26th, 33-39.

Article submitted on 05.02.2021

А. Арулрай, д-р, асист. проф., Науково-дослідний відділ економіки

Урядовий коледж Раджа Серфоджі

Танджавур - 613 005, Тамілнаду, Індія

Email: arulraj.antony@gmail.com

ORCID: 0000-0002-0767-8231

Р. Рена, д-р, проф. екон.,

Бізнес-школа NWU, Північно-Західний університет - кампус Мафікенг

Особиста скринька: X 2046, Ммабато, 2745, Південна Африка

E-mail: ravinder.rena@gmail.com

ORCID: 0000-0002-4156-8693

Scopus ID: 56441653000

ОПОСЕРЕДКОВАНИЙ ВПЛИВ НА СКОРОЧЕННЯ

БІДНОСТІ В ІНДІЇ ЧЕРЕЗ НАЦІОНАЛЬНУ ПРОГРАМУ ГАРАНТІЙ

СІЛЬСЬКОЇ ЗАЙНЯТОСТІ МАХАТМИ ГАНДІ

За останні кілька десятиліть в Індії значно зменшилися можливості працевлаштування в сільській місцевості. Тому уряд Індії запровадив Національну Програму Гарантій Сільської Зайнятості Махатми Ганді (НПГСЗМГ), щоб створити можливості зайнятості для сільських людей. Програма розглядається як просте рішення комплексної проблеми, якою $є$ викорінення бідності в сільській місцевості та безробіття в Індії. Метою цього емпіричного дослідження було розроблення нової моделі скорочення бідності в сільській місцевості Індії за допомогою цієї Програми. Новизна дослідження полягає у спробі розробити емпіричну дослідницьку модель, яка 6 сприяла НПГСЗМГ при відображенні рівня якості економічних послуг та іiі посиленню. Цей документ забезпечує альтернативне джерело засобів до існування, він матиме вплив 
на зменшення міграції, обмеження дитячої праці, полегшення бідності та створення сіл самоокупності сільських поселень завдяки створенню виробничих активів: дорожного будівництва, очищення водних резервуарів, роботи зі збереження грунту та води та ін. Документ вважають найбільшою програмою, спрямованою проти бідності у світі. У статті критично розглядався процес реалізації цієї Програми та їі вплив на засоби існування племен. У роботі використано методологію дослідження даних за допомогою структурованої анкети. Процедурою вибірки була стратифікована випадкова вибірка на основі талуків - Кумбаконам (Тайурурський район), Кееранур (Пудукотський район) та Нагаппатинам (Нагаппатинамський район) Тамілнаду (Південна Індія) за регіонами: південь, схід, центр, захід і північ. Під час вибору співробітники НПГСЗМГ з кожної категорії використовували вибірку на основі оціночних суджень та не-імовірнісну вибірку на основі зручності. Результати та висновки дослідження показують, що мільйони бідних сільських жителів із залученням до нових робіт за цією програмою змогли отримати роботу, яка підтримує їх життєзабезпечення. Зусилля спрямовуються на підвищення прозорості та підзвітності у впровадженні цієї програми - щоб забезпечити переваги бідних та нужденних жителів села. Регресійний аналіз показав, що ліквідація бідності вплинула на економічний та соціальний розвиток. Візуальне представлення результатів свідчить про взаємозв'язок цих розмірів розвитку, що призвели до суттєвого впливу на опосередкований фактор «Ліквідація бідності». У роботі запропоновано заходи ефективного впровадження програми для зацікавлених сторін.

Ключові слова: моделювання, сезонні ефекти, скорочення бідності, Махатма Ганді, Національна сільська гарантія зайнятості, якість обслуговування економіки, Індія та забезпечення якості обслуговування. 